
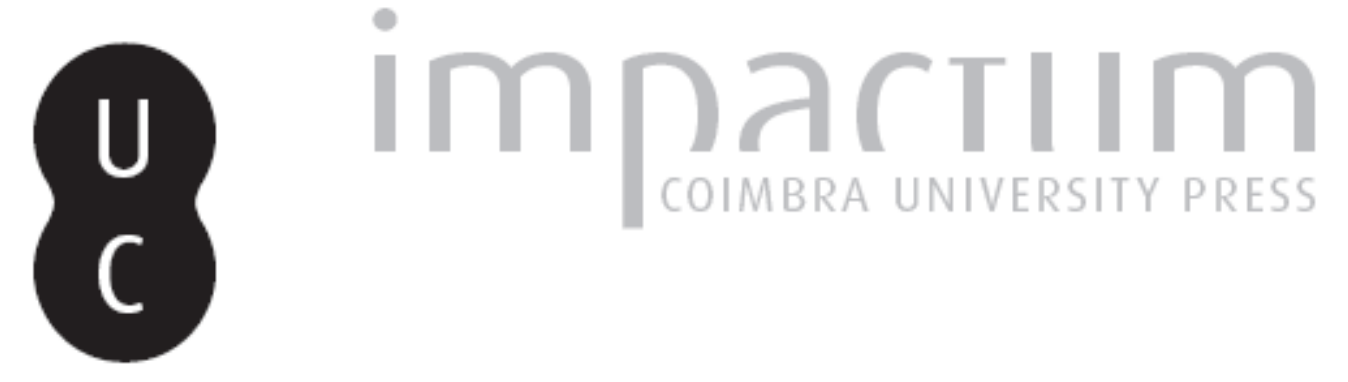

\title{
Os sentidos da Eleuthería na República de Platão
}

Autor(es): $\quad$ Araújo Junior, Anastácio Borges de

Publicado por: Annablume Clássica; Imprensa da Universidade de Coimbra

URL persistente:

URI:http://hdl.handle.net/10316.2/24302

DOI:

DOI:http://dx.doi.org/10.14195/1984-249X_9_3

Accessed : $\quad$ 26-Apr-2023 13:31:53

A navegação consulta e descarregamento dos títulos inseridos nas Bibliotecas Digitais UC Digitalis, UC Pombalina e UC Impactum, pressupõem a aceitação plena e sem reservas dos Termos e Condições de Uso destas Bibliotecas Digitais, disponíveis em https://digitalis.uc.pt/pt-pt/termos.

Conforme exposto nos referidos Termos e Condições de Uso, o descarregamento de títulos de acesso restrito requer uma licença válida de autorização devendo o utilizador aceder ao(s) documento(s) a partir de um endereço de IP da instituição detentora da supramencionada licença.

Ao utilizador é apenas permitido o descarregamento para uso pessoal, pelo que o emprego do(s) título(s) descarregado(s) para outro fim, designadamente comercial, carece de autorização do respetivo autor ou editor da obra.

Na medida em que todas as obras da UC Digitalis se encontram protegidas pelo Código do Direito de Autor e Direitos Conexos e demais legislação aplicável, toda a cópia, parcial ou total, deste documento, nos casos em que é legalmente admitida, deverá conter ou fazer-se acompanhar por este aviso.

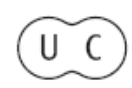




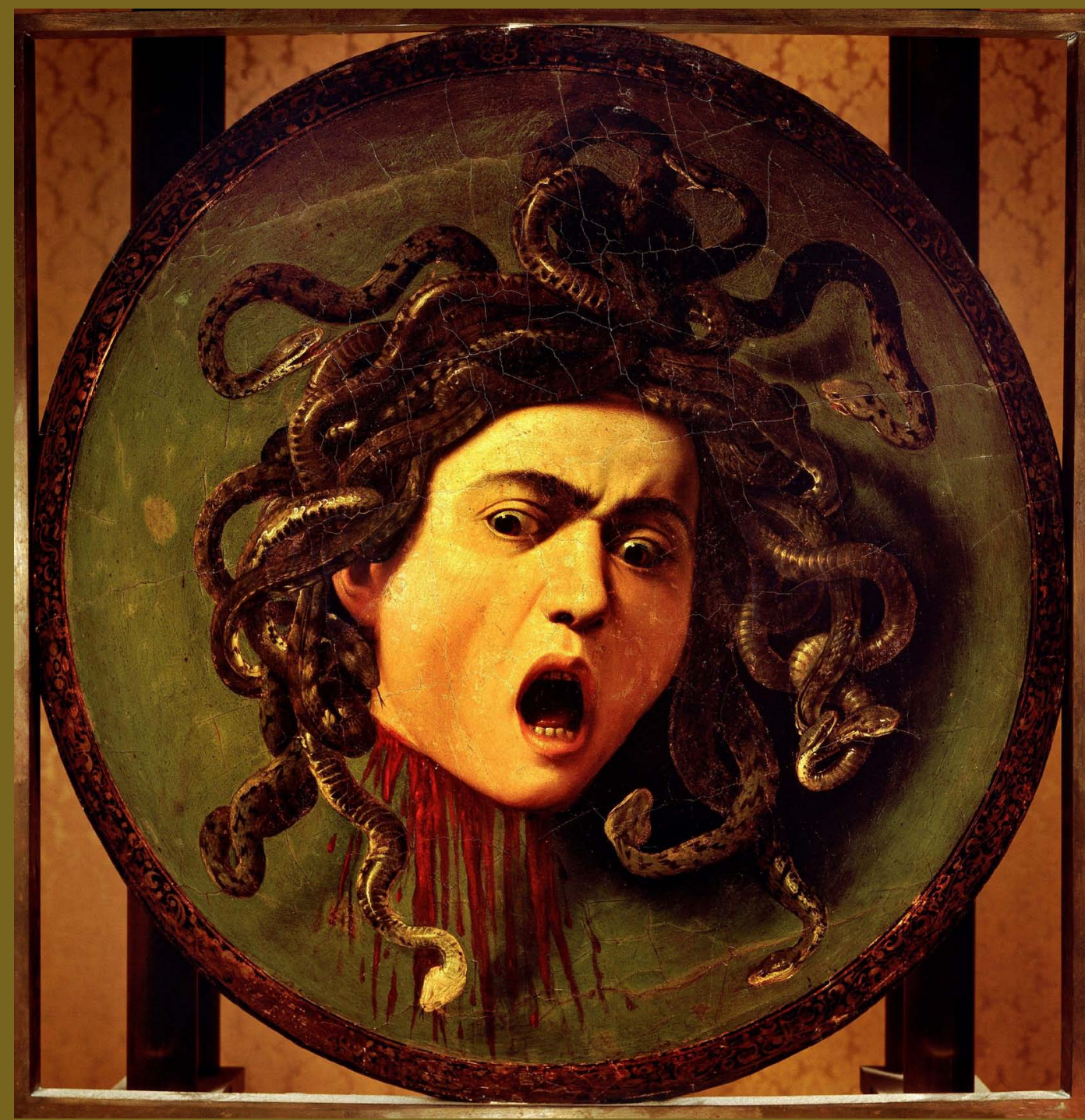

\section{R E V I S T A}
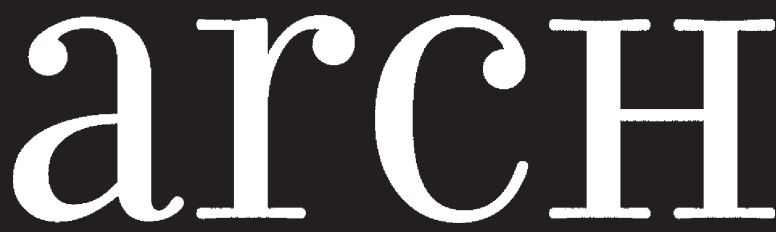
AS ORIGENS DO PENSAMENTO OCIDENTAL

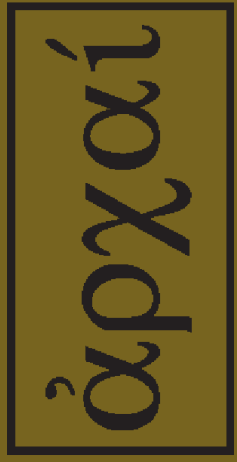

ARCHAI JOURNAL: ON THE ORIGINS OF WESTERN THOUGHT
arcHaI

arementam



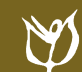

NNN 


\section{OS SENTIDOS DA ELEUTHERÍA NA REPÚBLICA DE PLATÃO}

ARAÚJO JR., A. B. (2012). "Os sentidos da Eleuthería na República de Platão". Archai n. 9, jul-dez 2012, pp. 27-36.

RESUMO: 0 sentido do termo eleuthería, similarmente a muitos outros conceitos na obra de Platão, não é unívoco. Mesmo se nos restringirmos ao diálogo República, encontraremos nele uma ampla gama de concepções que vão desde a acepção popular de 'dizer e fazer o que se quer', até a significação, mais propriamente filosófica do termo; vale dizer também daquela que envolve uma dimensão psicológica e moral, na qual o homem deve buscar agir de acordo consigo mesmo. Esta atividade ética, que Platão (2006) (seguir o modelo de citação indireta) insiste em chamar de política (Rep. IX, 592 a5 - a9), baseada no "cuidado de si" tornar-se-á uma pré-condição que prepara o homem para a vida junto aos outros homens e para outras ações derivadas, como o governo da pólis, a produção de leis e, também, para as atividades investigativas, tais como o diálogo e a dialética. Encontramos, pois, naquele diálogo, um verdadeiro embate entre algumas concepções rivais de eleuthería, por exemplo: Trasímaco acredita que o tirano é o mais livre dos homens (Rep. I, 344 a) enquanto Sócrates, ao final do diálogo, defende que o tirano jamais experimentou a liberdade (Rep. IX, 577 a). Assim, este artigo se propõe, então, investigar e circunscrever, a partir do exame da República, os sentidos da eleuthería, fixando a atenção no seu significado propriamente filosófico.

PALAVRAS-CHAVE: Platão; Ética; Eleuthería; Cuidado de Si; Agir;

ABSTRACT: The sense of the word eleutheria, similarly to many other concepts in the work of Plato, is not univocal. Even if we restrict ourselves to dialogue Republic, it will find
* Universidade Federal de Pernambuco. Presidente da Sociedade Brasileira de Platonistas

\section{Anastácio Borges de Araújo Junior*}

\section{Apresentação}

No livro IX da República, Sócrates procura examinar a origem do tirano e da tirania caracterizando-os na forma em que são gerados num clima de excessiva permissividade e falta de regras; e pelo desejo desmedido que os leva à loucura, invadindo sua alma, e também, a cidade. Neste clima, o tirano não se refreia frente aos impulsos selvagens e nem sequer sabe se controlar, o déspota realizará aqueles desejos que, antes, só se manifestavam em sonhos quando ainda guardava alguma reserva de pudor e ponderação. Rodeado por lisonjeadores e outros homens servis, não haverá quem o critique nem censure, pois qualquer limite ao seu comportamento será tratado com desprezo e violência. Assim, complementa Sócrates:

Portanto, vivem durante toda sua vida sem ser amigos de ninguém, sempre déspotas ou escravos do outro. A natureza tirânica jamais provará o sabor da liberdade e da verdadeira amizade." (PLATÃO, 2006, Rep. IX, 576 a4 - a6)

Ora, se Sócrates argumenta que o tirano é sempre desprovido da experiência da liberdade e da verdadeira amizade, é por que compreende a 
a multiple conceptions ranging from the popular meaning of 'saying and doing what you want', even the meaning, rather philosophical of expression; is to say also that it involves a psychological dimension, and moral, in which man must seek to act in accord with himself. This activity ethics, one which Plato insists on calling political (Resp. IX, 592 a5 - a9), based on "self care" will become a pre-condition that prepares the man for life with other humans and other actions arising as the government of the polis, the production of laws and also for investigative activities such as dialogue and dialectic. We find, therefore, that dialogue, a real disaccord between rival conceptions of eleuthería, eg Thrasymachus believes that the tyrant is the freest of men (Resp. I, 344 a) as Socrates, at the end of the dialogue, argues that the tyrant never experienced the freedom (Resp. IX, 577 a). Thus, this article proposes, then investigate and limit from the examination of the Republic, the meanings of eleutheria, fixing the attention on their philosophical meaning properly.

KEYWORDS: Plato, Ethics, Eleuthería, Self Care, Act.

semântica da eleuthería de outro modo que aquele defendido por Trasímaco, quando ainda no livro I da República, afirma que o Tirano, por meio de sua ação injusta, desfruta da máxima felicidade, pois sua ação é mais poderosa, livre e dominadora (Rep. I, 344 c5). Além disso, se a eleuthería é uma noção chave que orienta a descrição do homem e a cidade democráticos em sua gênese e desenvolvimento, tal noção parece ser diferente daquilo que é sugerido por Sócrates, em passagens mais ou menos claras, quando propõe a paidéia dos homens, estes são os que devem cuidar, manter, defender e preservar a cidade, denominados guardiões nos livros II, III e IV. Encontraremos, então, ao longo do diálogo, diversas concepções sob o mesmo nome, vários significados e compreensões em torno de eleuthería que exige uma pesquisa a fim de, minimamente, lançar alguma luz sobre o problema.

Neste trabalho, tentaremos elencar alguns dos sentidos de eleuthería na obra República, mostrando como eles rivalizam enquanto concepções de homem e de cidade e, ao final, tentaremos esclarecer em que consiste a eleuthería apresentada pelo personagem Sócrates na sua concepção de paidéia. Claro que se há um conjunto de características pertencentes ao sentido filosófico da eleuthería este precisa ser reconstruído e esperamos poder apontá-lo como um conceito com significado muito mais elaborado, complexo e refinado do que as concepções rivais. Antes de passarmos à pesquisa propriamente dita, algumas considerações preliminares se fazem necessárias.

\section{Considerações Preliminares}

Em primeiro lugar, sem que pareça abusivo, pretensioso ou mesmo redundante falar de uma influência aristotélica, gostaríamos de esclarecer estarmos deliberadamente retomando um aspecto do modo de investigar de Aristóteles e sem esquecer que o mesmo foi discípulo de Platão.

Referimo-nos aquele aspecto no qual ao inquirir qualquer tema, o Estagirita começa por compreender as dificuldades associadas a ele, quando levanta as várias opiniões acerca do problema e explicita as suas várias faces expressas nas muitas concepções correntes. Dizia Aristóteles : “quem ignora um nó não poderá desatá-lo" (ARISTÓTELES, ano, Metafísica B, 995 a 29-30). Assim, o pensador sempre inicia sua investigação a partir das opiniões correntes e divergentes acerca daquilo que ele pretende tratar, em geral, tentado superar as oposições diafônicas que, em geral, são parciais e insuficientes. Por isso, encontramos inúmeras vezes nos seus escritos a expressão légetai, o famoso 'se diz' ou 'é dito' a respeito de tantos assuntos investigados.

Curiosamente, este aspecto da pesquisa aristotélica reverberou, sempre, em nós quando líamos os diálogos de Platão e nos deparávamos com os vários personagens que discutem sobre determinados assuntos e ficava-nos evidente que estes personagens, muitas vezes, compreendem os conceitos de modos diversos. Lembremos que, invariavelmente, Sócrates, no contexto dos diálogos, solicita que seus interlocutores explicitem o que compreendem por uma definição ou pelo uso da um conceito. Neste sentido, muitas vezes no diálogo os personagens não se compreendem, pois estão usando os mesmos termos com sentidos completamente diversos. É o caso, por exemplo, de Trasímaco e Sócrates que parecem usar o termo kreítton, no livro I da República, 
em sentido ligeiramente diferente, pois o mesmo termo pode significar tanto "o mais forte", "o mais

1. Ver sobre 0 assunto 0 nosso artigo ARAÚJO JUNIOR, Anastácio Borges. "0s sentidos de kreítton no Livro I da República de Platão" in XAVIER, Dennys Garcia e CORNELLI, Gabriele (orgs.) A República de Platão: Outros Olhares. São Paulo: Loyola, 2011 págs. $197-207$

poderoso" quanto "o melhor". ${ }^{1}$ A ambiguidade do termo garante uma falta de entendimento e uma tensão entre os personagens. Parece-nos que, muitas vezes, as expressões utilizadas e não examinadas nem definidas entram em rotas de colisão, pois quando os personagens utilizam um conceito, nele projetam os seus modos de compreender o mundo. Assim, examinar os sentidos dos conceitos centrais e relevantes nas discussões mimetizadas pelos diálogos platônicos, defendidos pelos personagens envolvidos no diálogo, pareceu-nos, então, um modo fértil de compreender o que está em jogo na discussão dialogada. Compreender o nó, antes de ter qualquer pretensão em desatá-lo.

Entretanto, não devemos nos enganar: Platão não é Aristóteles. Enquanto este levanta, examina e sistematiza as várias opiniões e concepções dos seus predecessores e crê poder superá-los, aquele desenvolve um encontro entre homens que, quase que naturalmente, começam a investigar um determinado tema e se envolvem nos desdobramentos desta atividade investigativa.

Se a retórica filosófica aristotélica simula 0 pensamento ruminando a partir de outras opiniões, Platão mimetiza o mundo da vida e dos encontros nos quais os homens se interessam por compreender algo e, subitamente, começam a investigar. Nos escritos de Platão, o enunciado está sempre atrelado a certa situação dialógica, quer dizer, a fala pertence ao personagem determinado que esteja, continuamente, situado num contexto específico. 0s discursos destes personagens, como mostrou Monique Dixsaut (1985, p. 127s), são resultados do conhecer e não conhecer de cada homem que, por sua vez, é consequência da orientação do desejo num contexto cultural influente. A filosofia é uma atividade humana construída a partir de discursos que se associam a desejos e desejos que se expressam em discursos. Assim, não há nunca uma fala que seja neutra ou isenta de desejo e neste sentido, puramente racional. Os diálogos são mimetizações de falas de tipos humanos que se posicionam, desejam, tomam partido. A filosofia tem uma dimensão afetiva inexorável que está associada ao pensamento. Ou melhor, Platão nos ensina que a inteligência precisa se aliar com outras potências afetivas para combater as tendências egoísticas e tirânicas que também existem em nós. São estas forças e estes desejos, segundo o que é sugerido na paidéia socrática, que podem apoiar a inteligência e conduzí-la na busca filosófica pelo justo, bom e verdadeiro.

É bem verdade que sentimos um incômodo em não sabermos estabelecer quais personagens representam a filosofia platônica, nem conseguirmos identificar se existe e qual é a doutrina platônica subjacente às muitas vozes de um diálogo. Resulta que, muitas vezes, seremos tentados a reconstituir esta doutrina platônica por meio de algum critério estranho ao próprio diálogo, como por exemplo, selecionar alguns argumentos separando-os dos personagens e da situação de fala para reconstituir a lógica dos argumentos, ou ainda tentar uma reconstituição histórica de uma possível doutrina baseada em testemunhos indiretos. Doutro modo, teremos que tentar respeitar os seus escritos ancorados numa injunção em que a forma do diálogo, escolhida por Platão, tem íntima conexão com sua própria concepção de filosofia. E esta última é, obviamente, nossa opção de interpretação.

Nosso esforço deve, antes de tudo, elencar que elementos estão presentes nos diálogos que elucidem, ou melhor, sinalizem a concepção platônica de filosofia. Ao tentarmos sistematizar os sentidos da eleuthería na República, estamos explicitando, ao modo aristotélico, as várias opiniões rivais e dissonantes presentes no diálogo e os tipos humanos com suas concepções e seus desejos que são envolvidos no exame filosófico dirigido por Sócrates ao apurar cada opinião e exigir que cada discurso se autojustifique.

Podemos dizer que ao lermos os diálogos de Platão, há uma convicção que tem ganhado força em nós: a filosofia se faz com exame, argumentação e justificação, isto é: diálogo. Se a filosofia é diálogo, o diálogo platônico prepara-nos para a filosofia, não no sentido de que eles são preparatórios para uma doutrina qualquer, mas no sentido de que eles são a essência mesma da própria filosofia em sua atividade investigativa. Dito isso, passemos, então, a segunda consideração preliminar. 
0 termo eleuthería, segundo Chantraine ${ }^{2}$, vem do adjetivo eleútheros e em variantes como elaútheros, eleútharos e eloútheros, que tem o sentido de "livre" por oposição a doulos que teria o sentido de "escravo". 0 termo se expande para caracterizar aquilo que é digno de um homem livre, sua fala e seu comportamento. Por último, Chantraine aponta que Benveniste teria descrito o homem livre como aquele que é "membro legítimo" de certa comunidade em oposição ao escravo e estrangeiro; que estaria fora desta comunidade, muito embora Chantraine conteste como "indemonstrável" que o termo eleútheros se ligue, também, a uma raiz que indica "crescimento e desenvolvimento". Sem querer nos aprofundar nesta disputa filológica, o resumo que encontramos no Vocabulário de Benveniste é o seguinte:

Captamos as origens sociais do conceito de "livre". 0 sentido primeiro, ao contrário do que seríamos tentados a imaginar, não é "desembraçado de alguma coisa" [como em oposição ao escravo que vive em constrangimento ou sob a força]; é o de pertença a um tronco étnico designado por uma metáfora de crescimento vegetal. Essa pertença confere um privilegio que o estrangeiro e o escravo jamais conhecerão. (BENVENISTE, 1995, p. 321)

Segundo Benveniste, o termo eleútheros, longe de ter seu significado original negativo e oposto a doulos, tem o sentido positivo daquele que pertence a um determinado grupo de homens entre os quais se cresce e se desenvolve, tornando-se igual aos outros que são chamados assim de companheiros e amigos. Fora desta comunidade, todos os outros são considerados não livres, quer dizer estrangeiros, bárbaros e escravos que não conhecem o sentimento de pertencimento ao grupo, nem desfrutam daqueles aprendizados que os transformaram em "livres".

Eleútheros pode ser compreendido, então, como homem que pertence à comunidade e que se diz homem por pertencer a esta comunidade. Torna-se, pois, impensável a existência do homem sem comunidade ou da comunidade sem homem. Há uma interdependência clara entre os termos homem e comunidade. Eleútheros é aquele que pertence a um tronco comum, que se vincula a uma cepa, relativo a determinado povo. Neste sentido, crescer e desenvolver-se, até tornar-se eleútheros, significa, originariamente, desdobrar-se até se tornar homem num seio de uma comunidade que vive junta e dedica-se através da educação ao compartilhamento de certos conhecimentos, significados, valores e modo de ser. Como já afirmamos: todos os outros que não compartilham desta cultura, na medida em que não pertencem ao grupo, são destituídos de valor e no limite podem ser considerados não-homens: isto é, estrangeiros, bárbaros e até escravos. Converter-se e ser homem, verdadeiramente, é pertencer a um grupo étnico fora do qual não há homens verdadeiros. Daí o etnocentrismo que encontramos em diferentes grupos humanos e a visão de que a eleuthería é um atributo de um grupo restrito que transforma os participantes deste grupo, em verdadeiros homens que se reconhecem enquanto tais.

Entretanto, em todo mundo indo-europeu há outra característica que irá modificar e determinar, profundamente, este ideal de eleuthería: as comunidades começaram a se dividir em torno das principais funções de modo que se tornaram hierarquizadas segundo três ou quatro classes fundamentais: a dos sacerdotes, a dos guerreiros e a dos agricultores e artesões. Cada classe, então, irá desenvolver seu próprio ideal do que é ser homem e da excelência do homem, ideais estes bem diversos e através dos quais cada grupo de homens realizará um ideal de humanidade ao qual estão associadas certas qualidades específicas deste subgrupo determinado. Assim, surgirão os múltiplos valores das classes, uma espécie de pulverização dos muitos ideais de homem e de humanidade, cada qual ressaltando certos aspectos das virtudes e da experiência do ser homem.

A cultura grega, na sua diversidade geográfica, cultural e temporal, herdará este complexo de valores que resultará num conjunto rico de matrizes que orientarão os homens pelos seus ideais de ser homem. Só para dar um exemplo bastante conhecido, pois não podemos nos alongar neste ponto, até por que não possuímos competência para tal, no mundo Grego os valores heroicos com seu ideal de bravura, rapidez e astúcia serão exaltados por Homero, enquanto os ideais do trabalho, esforço e moderação, pertencente ao homem do campo, serão cantados por Hesíodo. São estas muitas matrizes que
2.NCHANTRAINE, Pierre. Dictionnaire Étymologique de la Langue Grecque : Histoire des Mots. Paris: Klincksieck, 1968. Ver termo eleutherós na pág. 336 
representam os ideais de ser homem que serão apropriadas por Platão, que tentará organizá-las segundo o critério da inteligência. Claro que o modo através do qual Platão conduz o problema, pelo personagem Sócrates, deixa claro que para o filósofo numa sociedade pensada e hierarquizada, a vida filosófica é a melhor maneira de viver a vida humana.

A partir dessas considerações, talvez, possamos compreender, numa dimensão mais profunda, a importância da discussão acerca das formas de governo desenvolvidas pelos gregos que nos parece, muitas vezes, trivial. Pensar sobre a melhor forma de governo é pensar sobre o melhor modo de ser homem, seu desenvolvimento e sua realização. Neste sentido, a eleuthería tornar-se-á a possibilidade de nos transformarmos, através da paidéia, em homens para viver junto aos outros homens. Parece-nos que Platão, ao escrever a República, provavelmente, respirava todos estes elementos que constituíam a problemática do homem, da pólis, e como resolver as tensões que brotavam da vida do homem na pólis. Confrontando-se com essas questões, além das concepções sofísticas que tentavam demonstrar, a partir da multiplicidade de modos de ser do humano, o caráter convencional destes; ou ainda utilizando-os para tentar naturalizar alguns, Platão teve que elaborar uma resposta de ampla envergadura que, ao mesmo tempo em que dialogasse com todas estas tendências e compreensões, tentasse, também, as unificar num ideal filosófico superior. A existência de diferentes formas pelas quais o homem se organizava nas várias cidades gregas não foi capaz de fazer com que Platão desistisse de tentar encontrar, através do lógos, a melhor forma de cidade.

Vejamos, agora, as ocorrências do termo eleuthería, e se podemos reconstituir algumas destas matrizes que orientaram os vários ideais de 'ser homem' e que no diálogo rivalizam com a eleuthería filosófica. Tentaremos justificar que a República é, então, uma defesa da vida filosófica como aquela que pode realizar melhor as capacidades humanas de modo que valha a pena ser vivida e, talvez, prepare o homem para a melhor vida possivel em comunidade. Esta dupla tarefa será realizada pelo desenvolvimento da potência dialética que o homem é capaz de exercer.

\section{As ocorrências do termo eleuthería}

Encontramos na República mais de cinquenta ocorrências do termo eleuthería e suas variantes, sem contar as ocorrências negativas do termo em aneleuthería. Seria inviável e mesmo maçante examinarmos aqui todas elas, de modo que escolhemos alguns passos mais significativos para discutir o tema, organizando essas passagens em três núcleos principais: o primeiro constitui aquele no qual Sócrates mostra que a paidéia dos guardiões visa à formação de homens livres; o segundo quando Sócrates examina a gênese do homem e da cidade democráticos e o terceiro, e último, quando se examina a origem da natureza tirânica. Tentaremos, mesmo assim, sermos breves ao examinarmos estes trechos, até por que eles são bastante conhecidos.

0 primeiro trecho selecionado situa-se no livro III da República, quando Sócrates avança na crítica à formação promovida pelos poetas, e começa a desaprovar alguns exemplos de textos poéticos como a fala de Aquiles que diz: "preferiria, no trabalho da terra, ser servo de um outro homem sem posses, sem grandes meios de vida, a ser senhor de cadáveres, todos eles já consumidos" (PLATÃ0, 2006, Rep. III, 386 c5 - c7; Odisseia XI, 489-491). Sócrates não aceita que se eduque crianças inculcando nelas medos como o temor à morte, por isso diz:

Palavras como estas e todas as outras da mesma espécie, pediremos que Homero e os outros poetas não nos queiram mal por eliminá-las, não por que não sejam poéticos e prazerosos de ouvir para maioria, mas porque, quanto mais poéticos forem, menos deverão ouvi-los crianças e homens que devem ser livres (eleútherous) e temer mais a escravidão que a morte. (Rep. III, 387 $b 1-b 6)$

Sócrates deixa manifesto que a paidéia tem como objetivo a formação de homens livres que enquanto tais não precisam de medos infundados, mas que eles devem temer a escravidão sob todas as suas formas. Logo mais à frente, ainda no livro III, Sócrates começa a nomear as características desejáveis deste homem livre: 
Por conseguinte, se conservarmos o primeiro argumento, de que nossos guardiões, deixando de lado todos os outros trabalhos, devem ser escrupulosos artesões da liberdade da cidade (demiourgoùs eleutherías tes póleos), sem se ocuparem com nada que não contribua para isso, sem fazer ou imitar outra coisa. Mas, se imitam, que imitem já desde a infância aqueles a quem convém imitar, isto é, os corajosos, os moderados, os piedosos, os livres e tudo que tem essas qualidades. Não pratiquem nem sejam hábeis no imitar atos próprios dos não livres ou outro vício para que não venham a tê-los na realidade, como fruto da imitação. Não percebeste que, se as imitações perduram desde a infância vida adentro, as imitações se tornam hábitos e natureza que mudam o corpo, a voz e o pensamento? (Rep. III, $395 b 8-d 3)$

Sócrates está aqui aplicando o princípio que orientou a divisão das tarefas na cidade, aquele que determinou que cada homem, para fazer bem sua função, deve se restringir a uma única atividade, àquela que the é mais própria segundo as suas aptidões naturais. 0 guardião deve ater-se a sua única tarefa que é trabalhar para garantir a liberdade dos homens e da cidade. Guardar a si mesmo e a cidade para que os homens, aí nascidos, se transformem em verdadeiros homens, eleútheroi.

Ao imitar algo, uma vez que a imitação é um modo de aprendizado primordial através do qual o que foi imitado torna-se hábito e depois natureza para o corpo, para a fala e, até, para o pensamento, o jovem deve imitar valores como a coragem, a moderação, a piedade, a magnanimidade e a liberdade. Temos, aqui, as qualidades morais desejáveis, no discurso socrático, ao homem livre. 0 homem livre deve ser corajoso para julgar aquilo que deve ser temido, moderado com relação aos próprios desejos e paixões e, por último piedoso e magnânimo, que são noções gêmeas ${ }^{3}$, para the garantir uma visão ampla daquilo que deve ser valorizado e estimado tendo em vista o seu próprio bem e o bem da cidade. Entretanto, Sócrates enraíza essas qualidades morais, que o guardião deve desenvolver e cultivar, em si e na cidade, na dinâmica psicológica que resulta da sua concepção de alma tripartida. Vejamos:
Ora a expressão 'mais forte que si mesmo' não é ridícula? Com efeito, quem é mais forte que si mesmo será também, sem dúvida, mais fraco que si mesmo e o fraco forte. Pois é da mesma pessoa que se diz isso em todos esses casos. (...) Mas a expressão significa que no interior do mesmo homem, em sua alma, existe algo que é melhor e algo que é pior, e, se o que é melhor por natureza tem domínio sobre o que é pior, a expressão usada é 'mais forte que si mesmo', o que é um elogio. Se, porém, sob a ação de uma educação má ou de certo convivio, o que nele há de melhor é dominado pelo que é pior, mas superior em tamanho, isso significa censura e reprovação, e é chamado 'mais fraco que si mesmo' e intemperante quem está nessa situação. (Rep. IV, 430 $e 11-431$ c3)

Segundo a psicologia desenvolvida na República, o homem é resultante de um agenciamento de múltiplas tendências. Se o raciocínio e a inteligência, cultivados pela educação e pelos hábitos, predominam, eles poderão tentar harmonizar os outros elementos da alma. Assim, quando o homem consegue unificar estas tendências pode moderar os seus desejos e sua irascibilidade, tornando-se temperante e corajoso, pois dirige sua fala e suas ações segundo as determinações da parte melhor, chama-se este homem "mais forte que si mesmo" (kreítto autou $^{4}$ ). Caso contrário, quando não se atinge uma unidade coordenada pelo pensamento, o homem será dirigido pelas outras tendências, sendo governado pelos elementos irascível e desejante, tornar-se-á um agenciamento pouco harmônico, pois os desejos são parciais, unilaterais e não possuem qualquer visão de conjunto. Tal situação leva o homem a certa desagregação de si mesmo, pois governado pelos muitos desejos tornar-se-á insatisfeito, escravo desses prazeres e desejos, a tais homens chamam-se "mais fracos que si mesmos" (étton autou).

Claro que o ideal de eleuthería no discurso socrático exige uma unidade mínima do homem de modo que se possa falar em "si mesmo". Assim, falar e agir de acordo consigo mesmo (práttein meth'autou $)^{5}$ exige um trabalho anterior de constituição deste "si mesmo" para então perseguir o ideal de liberdade e felicidade que norteia a vida do homem e da cidade. Muito embora, devemos ter
3. Em Rep. III, 402 b9 - c6, Sócrates repete a mesma lista de virtudes, mas substitui a santidade pela generosidade ou magnanimidade (megaloprepeia).

4. A expressão kreitto autou é traduzida geralmente como "senhor de si mesmo", porém para sermos coerentes com o primeiro livro do diálogo e mantermos certa unidade na obra é preferíve traduzirmos por "mais forte que si mesmo".

5. Ver a passagem em que Sócrates diz que a injustiça "parece ter uma força tal que, se vem a existir, seja numa cidade, seja numa estirpe, seja num exercito, seja em outro grupo social qualquer, em primeiro lugar, faz com que ela seja incapaz de agir de acordo consigo mesmo" (Rep. I, 352 a). 
cuidado para não cairmos em posições edificantes e edulcorantes a partir de concepções idealizadas, devemos perceber que este ideal ético estará sempre sob ameaça, pois a discórdia e o conflito se colocam sempre como possibilidades iminentes já que a harmonia alcançada é resultado de um agenciamento que tende a ser realizado e conservado a cada dia, de instante em instante.

Para cuidar deste agenciamento de tendências dissonantes que nos constitui, Sócrates, habilmente, identificou o elemento inteligente e calculador, pois ele é o único que tem visão da totalidade e do conjunto. A esta atividade de cuidado de si mesmo e da cidade, Sócrates chamou "phylakikê" (Rep. IV, 428 d6). 0 guardião do homem e da cidade orienta-se pelo conhecimento que the permite o cuidar de si, o observar-se, o velar por si. Saber e conhecer a si mesmo implica observar os efeitos que o falar e o agir têm sobre o próprio homem. Esta é a vida examinada. Na eleuthería socrática só depois que o homem é educado e desenvolve a capacidade de cuidar de si, estará apto para usufruir de sua liberdade. Este nos parece ser o sentido da formação humana proposta por Sócrates, ao preparar o homem para viver a liberdade junto aos outros homens. Devemos passar ao segundo núcleo de significação, aquele que surge no exame do homem e da cidade democráticos.

0 homem democrático, diferente do guardião, caracteriza-se pelo domínio dos desejos sobre o pensamento. Assim começa a descrição deste homem:

É que, evidentemente, um homem que tenha tais qualidades se revelará para nós como o homem democrático. (...) Em primeiro lugar, os homens não são livres nessa cidade? Não vigora em toda a cidade a liberdade e a garantia do direito de livre expressão e também a licença de nela se fazer o que se queira? (aute poiein oti tis boúletai) (...) Onde, porém, houvesse tal licença, evidentemente cada um poderia organizar para si um modo de vida particular que the agrade. (...) Seria principalmente sob essa forma de governo que haveria todas as espécies de homens. (...) Pode bem ser que essa forma de governo seja a mais bela entre todas... Como um manto multicolor, com muitas flores bordadas, assim também essa forma de governo, bordada com todos os tipos de caráter, pareceria belíssima. (Rep. VIII, 557 b1 - c7)

Sócrates descreve a principal característica da cidade e do homem democráticos o 'fazer o que se quer'. Este é o sentido popular da eleuthería que permanece até os dias de hoje. Cada homem organiza sua vida, fala e age de acordo com sua própria concepção de ideal. Não há regras compartilhadas pela comunidade exceto que a liberdade do homem é intocável. 0 homem democrático torna-se presunçoso, pois não se importa muito com a vida dos outros homens, mas deixa-os em paz na medida em que não é incomodado. Nesta cidade haverá todos os tipos de homens que inverterão os valores "atribuindo-lhes nomes bonitos, à desmedida chamam boa educação, à anarquia liberdade, à prodigalidade magnificência e à imprudência coragem." (Rep. VIII, 560 d8 - 561 a1) Vivem segundo estas concepções do seguinte modo:

(...) ele vivendo o seu dia-a-dia cedendo ao desejo do momento, ora embriagando-se e tocando flauta, ou bebendo só água e tentando emagrecer, ora exercitando-se, outras vezes também ficando sem nada e descuidando-se de tudo, ora ficando como se passasse seu tempo filosofando. Às vezes, dedicando-se à política e subindo à tribuna, diz e faz o que the vem à cabeça. Se um dia inveja guerreiros, passa para o lado deles; se inveja homens de negócios, é para lá que vai, e na vida dele não há posto a manter nem coerção que o obrigue, mas, ao contrário, chamando-a de doce vida, livre e feliz, vive-a durante todo o tempo. (Rep. VIII, 561 c6 - d7)

Eis a vida chamada de livre pela maioria, é uma vida sedutora, mas que na verdade carece de princípios e termina por colocar em risco a ideia de comunidade, e também, de homem. A pólis torna-se um amontoado de homens que não se reconhecem como companheiros da mesma situação. Insensíveis ao outro se sentem oprimidos pela pressão em resolver os seus próprios desejos. Nesta cidade não há unidade nem harmonia. 0 homem democrático entrega o domínio de si ao elemento apetitivo da alma. Vive constrangido e acuado pelos desejos que são insaciáveis e efêmeros. Resulta, então, uma 
vida volátil, sem objetivos, carente de princípios e de qualquer valor que the forneça finalidade. 0 democrático torna-se presa fácil de seus desejos e ali onde pensa que tem autonomia e liberdade encontra uma doce escravidão, na busca incessante por satisfazer um mestre inconstante e implacável. 0 tirano surgirá como paroxismo da vida democrática, ele levará ao extremo o ideal de liberdade democrática e encontrará, em si, a mais perversa escravidão que o homem pode conhecer. Passemos, finalmente, ao homem tirânico:

Então, quando os outros desejos zumbindo em torno dele, carregados de incenso, de perfumes, de coroas, de vinhos e de prazeres desenfreados, próprios de tais convívios, fazem que ele cresça até o seu máximo e, alimentando-o, criam nele o ferrão do desejo não-

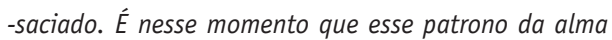
assume a loucura como escolta sua, entra em delírio e, se acolheu dentro de si opiniões e desejos que são tidos como nobres e ainda guardam algum traço de pudor, ele os vai matando e empurrando-os para fora de si, até ficar isento de temperança e enche-se de um delírio que lhe vem do exterior. (Rep. IX, 573 a4-b4)

0 tirano emergirá na atmosfera democrática como uma loucura daquele que percebe a impossibilidade de saciar o desejo e rompe com qualquer senso ou pudor. Guia-se, então, pela loucura fruto de seu desespero defronte a uma tarefa impossível em realizar: satisfazer todos os seus desejos e impulsos. Os desejos que o perturbam não são ligados à esfera do necessário como eram no homem democrático, mas ligados à experiência do supérfluo. Como em sonho, "não se absterá diante de nenhum homicídio, de nenhum alimento, de nenhuma ação." (IDEM, Rep. IX, 575 a1) Por não experimentar a satisfação, já que tenta apagar um incêndio com combustível, o tirano ampliará seu leque de desejos, experiências e prazeres. Vivendo muitas vezes os resíduos das vidas alheias, esvaziado de si mesmo, no íntimo, quando passa a fúria do prazer, encontra-se deserto e em solidão:

Um verdadeiro tirano é um verdadeiro escravo, capaz das maiores adulações e servilismos, um bajulador dos piores homens. Sem satisfazer sequer um de seus desejos, revelar-se-á ao contrário, carente de muitas coisas e verdadeiramente pobre, se houver quem seja capaz de contemplar toda a sua alma, e durante toda a sua vida estará cheio de medo, de espasmos e dores.

(Rep. IX, 579 d9 - e5)

0 tirano, diferente do homem democrático que conseguia viver junto aos outros homens, tem como ideal de eleuthería a realização plena de seus desejos egoístas e infantis. Suportará com dificuldades qualquer frustração. Os outros homens se transformam, sempre, em meios para realizar seus desejos desmedidos e insaciáveis. Como vê as coisas e o mundo a partir de sua perspectiva imatura, sente-se sempre ameaçado pela existência do outro. Sua liberdade é atravessada por dores, medos, desconfianças e insaciabilidade. Não conhece a liberdade filosófica, pois não conquistou a unidade de si mesmo, e nem pode experimentar os sentimentos de amizade, pois o outro é, sempre, hostil ou adulador. Vive triste, só, fragilizado pela falta de companhia de si mesmo e dos outros. Assim, não poder fazer jamais aquilo que quer, na medida em que desconhece o que seja "si mesmo".

Claro que sempre se pode argumentar que se o pensamento constitui o próprio homem e se os desejos também fazem parte dele, por que seria mais legítimo entregar-se ao pensamento no lugar dos desejos? A questão que nos parece fundamental, é que o desejo não poderá, por sua própria natureza, jamais organizar o próprio homem. Por isso, Sócrates conclui sobre o homem de natureza tirânica o que se aplica também ao homem democrático: “Logo, a alma tiranizada não fará de modo algum o que quer - refiro-me à alma na sua totalidade; mas arrastada sempre à força por um desejo furioso, está cheia de perturbações e de remorsos." (Rep. IX, 577 e1 - e3)

0 tirano poderá realizar todos os seus impulsos, mas não poderá experimentar satisfação na totalidade de si e como não pode recusar a compreensão do resultado das suas escolhas, vive cindido. A inteligência, como princípio constitutivo da natureza humana pode ser instrumentalizada, escravizada, desvalorizada, entretanto, jamais poderá ser extirpada. Assim, visto como totalidade complexa, a 
alma dos homens democráticos e tiranos não pode fazer o que quer, no sentido próprio da expressão, pois para fazer o quê se quer é necessário envolver, na unidade da escolha, a própria inteligência. Fazem eles, no máximo, aquilo que experimentam como desejo numa atuação ou adesão impensada ao elemento apetitivo da alma. 0 pensamento por sua capacidade integradora e unificante é o único elemento que poderá dar unidade à experiência interior de multiplicidade do homem. Agir de acordo com a inteligência é compreender que só ela poderá mediar a multiplicidade de tendências e desejos que nos dilaceram. Ora, este sentido de eleuthería oriundo da paidéia, tornou-se o ideal de liberdade socrático-platônico que o diálogo sugere ser a methor possibilidade de viver a vida humana. A vida filosófica é a melhor forma de vida, pois enquanto vida examinada coloca-a a luz da inteligência e logra a vida humana na sua especificidade. Para encerrar nosso artigo, gostaríamos de tentar dar uma palavra acerca da relação entre esta concepção de eleuthería com a descrição da metáfora da caverna, realizada no livro VII de República.

\section{Conclusão}

0 tema da alegoria da caverna é complexo, envolve muitas polêmicas e não gostaríamos de banalizá-lo, mas dar sobre ele uma breve palavra. Muito se discutiu e ainda há que se discutir em que medida a proposta de libertação da condição de cativo é algo realizável pelo homem, enquanto homem que é imperfeito, possui corpo e é finito.

Parece-nos que a eleuthería como harmonização de si mesmo é pré-condição ética para a busca do conhecimento das coisas que são tal como preconizadas no livro VII da República. Neste sentido, a harmonização de si seria pré-condição para o exercício de uma boa arte dialética. Quer dizer, a alegoria da caverna alinhada com duas outras imagens, a do sol e da linha dividida sugere que a busca pela inteligibilidade é uma transformação que operamos em nós mesmo pela potência dos conhecimentos matemáticos e pela dialética.

A dialética parece ser a busca, propriamente dita, por níveis de inteligibilidade mais amplos, busca esta regida pelo diálogo. É difícil acreditamos que a alegoria da caverna descreva uma situação plenamente realizável para o homem, enquanto vivente que possui alma e corpo. 0 seu sentido, parece-nos, antes o de uma metáfora que deve ser adaptada às condições humanas. Cada vez que compreendemos algo, ganhamos inteligibilidade e saímos da caverna, porém nossa condição sensível não poderá ser ultrapassada, pelo menos não nesta vida e de maneira definitiva. Voltamos à caverna e temos que retomar e fazer todo o percurso novamente. Neste sentido, os diálogos de Platão estão sempre deixando para o outro dia o aprofundamento de temas que escaparam na investigação. $0 \mathrm{u}$, simplesmente retomando aporias que constituem o horizonte do próprio homem.

Neste sentido, lembro-lhes que a dialética, no diálogo Sofista, é chamada de ciência dos homens livres, atividade daqueles que dedicaram a vida ao exame e puderam harmonizar-se, minimamente, para estarem juntos aos outros homens, amigos e companheiros, e que possam investigar as coisas na companhia um do outro. Assim, acreditamos que a liberdade no seu sentido filosófico é uma submissão à inteligibilidade, pois não podemos recusar este princípio em nós, entre os homens e mesmo no cosmos. Este princípio, por ser capaz de nos fazer compreender, mostra-nos, também, a nossa não autossuficiência, isto é, a necessidade que temos do outro, não só para as coisas da vida, mas para investigar filosoficamente como amantes da sabedoria que somos. Há uma passagem em que Platão deixa isto muito claro que se encontra no diálogo Protágoras:

Nessa altura, Protágoras, envergonhado, como se me afigurou, com as palavras de Alcibíades e a insistência de Cálias e de quase todos os circunstantes, decidiu-se, não sem algum trabalho, pelo reatamento da discussão, declarando que eu poderia interrogá-lo e que ele passaria a responder. Assim, lhe disse: - Não penses, Protágoras que ao discutir contigo move-me outro intuito que não seja o de esclarecer certos problemas que presentemente me suscitam dúvidas. Sou da opinião que Homero tinha razão, ao dizer: Quando são dois, se um não vê, o outro pode perceber o caminho. Pois desse modo ficamos os homens muito mais bem aparelhados para qualquer ato, 
palavra ou pensamento. Por isso quando a um, apenas, ocorre qualquer pensamento, sai à procura de alguém a quem possa comunica-la, até vê-la confirmada." (PLATÃO, ano, Protágoras, 348 c5 - d5)

A paidéia como preparação para a eleuthería filosófica resulta na submissão à inteligibilidade. Esta submissão leva-nos, necessariamente, a reconhecer a fragilidade de nossas descobertas que precisam ganhar corpo, serem fortalecidas. Talvez, nossa única chance de êxito é o compartilhamento de nossas opiniões, admitindo a necessidade do outro, para que possamos testá-las e estar mais bem aparelhados na busca pela verdade. A liberdade e a amizade parecem estar assim inexoravelmente entrelaçadas como conceitos gêmeos, tal qual se mostrou na primeira citação que fizemos de Sócrates, ao constatar que o tirano jamais experimentou a liberdade e deste modo, desconhece a verdadeira amizade.

\section{REFERÊNCIAS BIBLIOGRÁFICAS}

BENVENISTE, Émile. (1995) 0 Vocabulário das Instituições Indo-Européias. Campinas, Unicamp.

CHANTRAINE, Pierre. (1968) Dictionnaire Étymologique de la Langue Grecque : Histoire des Mots. Paris, Klincksieck.

DIXSAUT, Monique. (1985) Le Naturel Philosophe: Essai sur le Dialogues de Platon. Paris, Vrin.

MULLER, Robert. (1997) La Doctrine Platonicienne de la Liberté. Paris, Vrin.

PLATÃo. (2006) A república: ou sobre a justiça, diálogo político. Tradução Anna Lia Amaral de Almeida Prado. São Paulo, Martins Fontes.

PLATO. (1991) The Republic. Translated, with notes, an interpretative essay, and a new introduction by Allan Bloom. New York, Basic Books.

VEGETTI, Mario. Antropologias da Pleonexía: Cálicles, Trasímaco e Gláucon em Platão. Boletim do CPA, Campinas, Ano VIII, Número 16, págs 9-26.

Recebido em novembro de 2011. Aprovado em março de 2012. 